\title{
The history of paper money in Vietnam
}

\author{
Luong Anh Phuong
}

AISDL

Hanoi, February 18, 2021

Paper money is a medium of exchange printed in paper for goods or services in an economy [1], which first appeared in the Tang Dynasty of China (during the 7th century) and developed in the Song Dynasty (during the $10^{\text {th }}-11^{\text {th }}$ century). However, at that time, paper money (often known as a "jiaozi") was used as "promissory notes" between merchants and wealthy nobility and could not replace coins. Modern paper money only was used as a medium of exchange from the $17^{\text {th }}$ century in Europe [2].

In Vietnam, the first paper money was issued and circulated in 1396 under the Ho Dynasty. However, the above new policy of King Ho Quy Ly was protested by almost all citizens at that time leading to the invasion and domination of the Ming Dynasty of China within more than 20 years (1407-1428) [3]. In 1885, under French domination, paper money appeared in Vietnam one more time with the name "French Indochinese piastre" [4].

The official paper money of Vietnam (Vietnam Dong) was born in November 1946 [5]. At that time, the State Bank of Vietnam did not establish; therefore, each note has the picture of Uncle Ho and the phrase "Việt Nam Dân chủ Cộng hoà" (roughly translated: Democratic Republic of Vietnam) in the national language and Chinese [4]. From there to 1954 , the "French Indochinese piastre" together with Vietnam Dong was circulated legally in Vietnam, in which Vietnam Dong was used popularly in the North and the Central; the "French Indochinese piastre" was used around the country [6].

From the first issue of Vietnam Dong in 1946 to now, the Vietnamese government changed the form of paper notes in material, denominations, structure, and color five times. The first time was on May 12, 1951, the State Bank of Vietnam was organized and undertook the work of money issuance. The second time was in February 1959, under 
the Decision of Income Redistribution of the Vietnamese government. The third time was in 1975, with currency unification between the North and the South after Reunification Day (April 30, 1975). The fourth time was in 1985, before the serious scarcity of cash in payment, the Vietnamese government announced to exchange money at a rate of 10 VND (old money) $=1$ VND (new money) to serve revolution of price and salary with three denominations (10, 20, 50 VND). Under the impact of inflation, in 1990, the money notes of 10.000 VND and 20.000 VND replaced the old denominations. The denomination of 50.000 VND was issued in 1994, and the denomination of 100.000 VND was issued in 2000. The first polymer money of Vietnam appeared in 2003. The cotton money with denominations of $1.000 \mathrm{VND}, 2.000 \mathrm{VND}$, and $5.000 \mathrm{VND}$ and the polymer money with denominations of 10.000 VND, 20.000 VND, 50.000 VND, 100.000 VND, 200.000 VND, and 500.000 VND are circulated together. The polymer money noted the last change of paper money in Vietnam until the present time.

Paper money, with the historical mission of facilitation in payment and storage, has become familiar with Vietnamese citizens in particular and citizens worldwide in general. The development of Industrial Revolution 4.0 and the impact of the Covid-19 pandemic make e-payments popular, the extinction of money paper is a trend that has been forecasted around the world. I hope that this essay will become a beautiful memory of people who have lived in the period of "paper money."

\section{References}

[1] Tracy, P. (2021). Paper Money Definition \& Example. Investing Answers. Retrieved February 13 2021, from https://investinganswers.com/dictionary/p/paper-money.

[2] TIME. (n.d.). Top 10 Things You Didn't Know About Money. TIME. Retrieved February 14 2021, from http://content.time.com/time/specials/packages/article/0,28804,1914560 19145 58 1914593,00.html.

[3] Pham, H. (2016). Tiền thật, tiền giấy, và chuyện về Hồ Quý Ly. Nghiên Cứu Lịch Sử. Retrieved 14 February 2021, from https://nghiencuulichsu.com/2016/11/29/tienthat-tien-giay-va-chuyen-ve-ho-quy-ly/. 
[4] Bao Duy. (2017). [Lịch sử tài chính]: Tiền giây Việt Nam qua các thời kỳ. VietnamFinance. Retrieved 14 February 2021, from https://vietnamfinance.vn/lich-su-tai-chinh-tien-giay-viet-nam-qua-cac-thoi-ky20171128174136017.htm.

[5] Chính, P. M., \& Hoàng, V. Q. (2009). Kinh tế Việt Nam: Thăng trầm và đột phá. Nxb Chính trị Quốc gia, Hà Nội.

[6] Wikipedia. (2021). Đồng (tiền Việt Nam Dân chủ Cộng hòa). Wikipedia. Retrieved 14 February 2021, from https://vi.wikipedia.org/wiki/Đồng_(tiền_Việt_Nam_Dân_chủ_Cộng_hòa) 